\title{
Preventing and Combating Corruption in the European Union: The Practice of Member States
}

\author{
Maryna O. Dei*, Iryna S. Skliar ${ }^{\dagger}$, Anatolii Ie. Shevchenko ${ }^{\ddagger}$, \\ Andriy Cherneha ${ }^{\S}$ and Oleksii V. Tavolzhanskyi ${ }^{\Im}$
}

\begin{abstract}
Overcoming corruption is extremely important, as it is a danger to the state, society, and the individual. Of particular note is the experience of European Union member states that have implemented anti-corruption programs, achieved the necessary positive results, and laid the foundations for sustainable socio-political development, in particular in the context of guaranteeing national security. The aim of the study can be described as the analysis and detailed characterization of anti-corruption legislation and strategies to prevent corruption at the national and supranational levels of the European Union. The methodological basis of the work is scientific methods based on the requirements of objective and comprehensive analysis of social phenomena of a legal nature. A number of general scientific research methods were used in this study. The following methods can be distinguished: semantic and system analysis, discourse, methods of induction and deduction, historical-legal and formal-legal methods, and others. The article offers a detailed overview and thorough consideration of legal instruments of the Member States of the European Union on corruption and the relevant anti-corruption legislation of the European Union Member States.
\end{abstract}

\section{INTRODUCTION}

The world community has been discovering, in the last few decades, genuine interest in the problem of combating corruption, and foreign experts and scientists make a lot of effort to master all aspects of this phenomenon. As the problem of corruption crosses any interstate and interdisciplinary boundaries, and at the same time covers almost all spheres of life, its study is comprehensive and consistent, at the global level,

\footnotetext{
Department of Constitutional and Administrative Law, Faculty of Law, National Aviation University, Kyiv, Ukraine. Law Institute, Kyiv National Economic University (named after Vadym Hetman), Kyiv, Ukraine.

Department of History and Theory of Law and State, and Constitutional Law, University of the State Fiscal Service of Ukraine, Irpin, Ukraine.

5 Department of Public and Private Law, Faculty of Law and International Relations Borys Grinchenko Kyiv University, Kyiv, Ukraine.

Department of Criminology and Criminal and Executive Law, Yaroslav Mudryi National Law University, Kharkiv, Ukraine.
}

(C) The Author(s) 2021. Published by Oxford University Press. All rights reserved. For permissions, please e-mail: journals.permissions@oup.com. 
and attention is paid primarily to the nature of origin and development of tools to, if not overcome, then at least to localize and minimize its extent and impact on society. Corruption undermines the rule of law, undermines state institutions and democracy, and has negative effects on the economy and the political situation. ${ }^{1}$ Most countries suffer from deeply entrenched corruption that hampers economic development, undermines confidence in democratic values, and undermines the rule of law. As a result, corruption can undermine citizens' confidence in democratic values and processes in a country.

The pernicious effects of corruption lead to a loss of authority in the eyes of citizens, a distortion of the moral foundations of society, a decline in compliance with the law, a loss of social solidarity, the spread of legal nihilism and indifference, and an increase in crime. $^{2}$ The main purpose of combating corruption is to identify and overcome its preconditions and consequences and to expose corruption and its perpetrators. The prevention of corruption in the country is the progressive democratization of all spheres of public life and the development of civic awareness and activity in a democratic State. ${ }^{3}$

It should be noted that in the Sustainable Development Goals 2030, the international community has recognized the detrimental effects of corruption on economic and social development and has committed itself to significantly reducing corruption and bribery in all its forms. ${ }^{4}$ According to the 2019 Corruption Perceptions Index, calculated annually by the international organization Transparency International (according to which 100 points is an indicator that corruption is almost non-existent in the country, and 0 points is an indication of the highest level of corruption in the public sector), most EU Member States received quite high rates, which is evidence of a low level of corruption within the EU. For example, in the top ten countries with the lowest level of corruption are six EU member states, namely: Denmark, Finland, Sweden, the Netherlands, Germany, and Luxembourg. ${ }^{5}$

In addition, Eurobarometer statistics from 2020 demonstrate that corruption is unacceptable to the vast majority of Europeans (69 per cent), although a minority of Europeans believe that corruption affects their daily lives ( 26 per cent). ${ }^{6}$ Corruption has always been seen as a threat to the EU's financial interests and as a threat to the very existence of the European Union. In addition, corruption is also a serious threat to the domestic market. Moreover, the political consequences of corruption can also be devastating for the European Union, as declining public confidence in the EU institutions could jeopardize the process of European integration as a whole. ${ }^{7}$ It should be

\footnotetext{
R Razzante 'The Fight against Corruption' (2019) <https://www.adrioninterreg.eu/wp-content/uploads/2019/11/TheFight-Against-Corruption.pdf>.

O Cakhan 'Corruption in Modern Ukraine as a Source of Destructive Power' (2015) 4 Visnyk Natsionalnoho Universytetu Yurydychna Akademiia Ukrainy imeni Yaroslava Mudroho 114.

O Shevchenko 'Basic Principles of Anti-corruption' (2011) 1 Visnyk Vyshchoi Rady Yustytsii 132.

General Assembly 'Transforming Our World: The 2030 Agenda for Sustainable Development' (2018) <https://www. ua.undp.org/content/ukraine/uk/home/library/sustainable-development-report/the-2030-agenda-for-sustainabledevelopment.html> (11 May 2018).

Transparency International (2019) 'Corruption Perceptions Index - 2019’ <http://cpi.ti-ukraine.org/\#/> (2 June 2021). European Commission 'Special Eurobarometer Report on Corruption 2020' (2019)<https://ec.europa.eu/commfrontoffice/ publicopinion/index.cfm/survey/getsurveydetail/instruments/special/surveyky/2247> (10 June 2020).

P Szarek-Mason The European Union's Fight against Corruption: The Evolving Policy towards Member States and Candidate Countries (Cambridge: Cambridge University Press 2010).
} 
noted that there is an anti-corruption system at the EU level, as well as an EU acquis on anti-corruption, which is mandatory for all EU Member States as well as for candidate countries wishing to join the European Union. In view of all the above, it is extremely important to study the practice of the Member States of the European Union in the field of anti-corruption regulation.

Moreover, corruption affects virtually every country in the world and has a very long history. Nowadays, low levels of corruption are recorded in the EU member states such as Denmark, Finland, Sweden, the Netherlands, Germany, and Luxembourg. In this aspect, it is extremely important to study theoretically the experience of these countries and the European Union as a whole in order to implement effective anti-corruption practices. Among the scientists who have studied the world experience of preventing and combating corruption, the following should be mentioned: O Vasylieva, ${ }^{8}$ P Didyk, ${ }^{9}$ Szarek-Mason, ${ }^{10}$ V Trepak, ${ }^{11}$ O Novikov, ${ }^{12}$ T Khabarova, ${ }^{13}$ L Holmes, ${ }^{14}$ A Salminen, ${ }^{15} \mathrm{H}$ Shinkai, ${ }^{16}$ and others.

For example, H Shinkai stressed that corruption is a major problem of society, capable of threatening the stability and security of societies, undermining the values of democracy and morality, threatening social, economic, and political development, and threatening peace in general. ${ }^{17}$ It should be noted that today in the European Union the concept of 'corruption' is defined as 'abuse of power for private gain', which is a rather broad concept, and accordingly somewhat complicates the application of this definition. In this regard, Szarek-Mason notes that the EU Commission's definition of 'corruption' is broad, goes beyond current EU law and focuses on active or passive bribery; in addition to a narrow criminal definition, it also covers the socio-economic element aimed at preventing corruption in the context of good governance. ${ }^{18}$

At the same time, S Didyk analyzed the question of the history of combating bribery, which provides modern researchers with instructive lessons that need to be mastered,

8 O Vasylieva 'Foreign Experience of Anti-corruption Activities in Public Authorities' (2019) 13 Investytsii: Praktyka ta Dosvid 64.

$9 \quad$ S Didyk 'Formation and Development of Legislation on Combating Bribery of Judges in Ukraine' (2012) 2 Chasopys Kyivskoho Universytetu Prava 288.

$10 \quad$ See Szarek-Mason, $\mathrm{n} 7$.

11 V Trepak 'International Experience in Implementing a System of Anti-corruption Measures' (2015) 2 Yurydychnyi Chasopys Natsionalnoi Akademii Vnutrishnikh Sprav 238.

12 O Novikov 'Legal Regulation of Compensation for Damages Caused by Corruption Offenses' (2017) 4 Chasopys Kyivskoho Universytetu Prava 223.

13 T Khabarova 'Foreign Experience in Preventing Corruption' (2019) 27 Visnyk Kharkivskoho Natsionalnoho Universytetu imeni V.N. Karazina 75.

${ }_{14}$ L Holmes 'Different Paths to Curbing Corruption: Lessons from Denmark, Finland, Hong Kong, New Zealand and Singapore' (2015) 3 Asian Journal of Political Science 104.

15 A Salminen 'Control of Corruption: The Case of Finland, in Jon S. T. Quah, Different Paths to Curbing Corruption: Lessons from Denmark, Finland, Hong Kong, New Zealand and Signapore' (2013) 23 Research in Public Policy Analysis and Management 230.

16 H Shinkai Combating Corruption in Central and Eastern Europe (Rome: United Nations Interregional Crime and Justice Research Institute 1998).

17 Ibid.

18 Ibid; LO Samilyk, VO Maliarova, OV Dzhafarova, TI Gudz and VB Kovalchuk 'Complementary Medicine: International Experience of Functioning and Specific Features of the Application in Ukraine' (2019) 72 Wiadomosci Lekarskie 1104. 
known and applied. ${ }^{19} \mathrm{R}$ Manhur studied the problematic issues of determining the subject of the offer and giving a bribe. ${ }^{20} \mathrm{O}$ Novikov conducted a study of the legal regulation of compensation for damages caused by corruption offenses. ${ }^{21}$ At the monographic level, G Kokhan studied the phenomenon of political corruption, ${ }^{22}$ and D Mykhaylenko studied the fight against corruption by means of criminal law. ${ }^{23}$ A Kyslyi studied the activities of law enforcement agencies in the field of preventing and combating corruption. ${ }^{24}$

O Shevchenko studied the principles of combating corruption such as the rule of law; legality, systematics; complexity; objectivity; practical orientation and radical measures; scientific validity; economic feasibility; interaction of power structures with institutions of society and the population; optimality and efficiency; and objectivity. ${ }^{25}$ At the same time, $\mathrm{T}$ Ilyenok noted that the main factors contributing to the spread of corruption are as follows: deteriorating crime situation, high inequality of income distribution, lack of social protection in some countries, and increasing economic potential and annual increase in financial revenues in the form of foreign investment in others. $^{26}$

\section{Methodological Framework}

In the process of studying, the practice of the member states of the European Union in the field of anti-corruption regulation, first of all, the general legislation of the European Union on the fight against corruption, which applies to all member states, was analyzed. Next, we analyzed the national legislation of the European Union member states, which are among the countries of the world with the lowest level of corruption. Based on the study of these data, a comparative analysis of the practice of different countries on this topic was carried out. In the end, conclusions were drawn, as well as perspectives and recommendations in the field of combating corruption.

Materials and research methods were selected taking into account the goals and objectives set in the article. In addition, the work used a set of regulatory principles, techniques, and methods, by means of which knowledge about the practice of the European Union member states in the field of anti-corruption regulation was achieved. To conduct the research, a number of methods were used in the article, as well as various materials. In particular, the author used a number of general scientific and special legal scientific methods. The methodological basis of the study is a set of methods and techniques of scientific understanding inherent in the science of jurisprudence in general and the science of international law in particular.

See Didyk, n 9.

20 R Manhur 'Problematic Issues of Determining the Subject of the Offer and Giving a Bribe' (2012) 1 Chasopys Kyivskoho Universytetu Prava 330.

$21 \quad$ See Novikov, $\mathrm{n} 12$.

22 HV Kokhan The Phenomenon of Political Corruption: Theoretical and Methodological Analysis (Kyiv: National Institute for Strategic Studies 2013).

23 DH Mykhaylenko Counteraction to Corruption Crimes by Means of Criminal Law: Conceptual Bases (Odesa: Helvetica Publishing House 2017).

24 AM Kyslyi 'Prevention and Counteraction of Corruption and Law Enforcement Activities' in Handbook for Higher Education Institutions (Kyiv: Kyiv Liudmyla 2020).

See Shevchenko, $\mathrm{n} 3$.

T Ilyenok 'Fight against Corruption: International Experience' (2013) 2 Yurydychna Nauka 73. 
The philosophical and ideological basis of the study is the general provisions, principles and paradigms of dialectics, hermeneutics, phenomenology, and synergetics. To achieve scientific objectivity of the results, the whole complex of philosophical, general scientific, special scientific, and specific scientific methods is used. In the work, formal legal and comparative legal methods are widely used in the study of the features of the anti-corruption activities of international bodies and organizations at the universal and regional (within the legal space of the Council of Europe) levels and in the discovery of common features and differences in the international legal regulation of the application of measures to combat corruption: historical and legal-in determining the genesis of the transformation of the problem of corruption from a purely domestic into an international legal one; dialectical, structural, and functional methods and abstraction method-when identifying the specifics of international cooperation in the fight against corruption and determining the main directions of anti-corruption cooperation in the bodies of the European Union; the formal-logical method (analysis and synthesis) and the inductive method are used in the study of existing theoretical views on the legal characteristics of corruption as a generic phenomenon, and theoretical developments on international legal responsibility for corrupt acts and the normative regulation of relevant public relations. An integrated approach to the analysis of the issues under study and the use of these methods made it possible to consider comprehensively the development and current state of cooperation between the European Union states in the fight against corruption.

Methods such as discourse and content analysis were also applied, which made it possible to determine the boundaries of the practice of European Union member states in the field of anti-corruption regulation, as well as to determine the main legal provisions governing this issue. Also, the article is based on the laws and principles of dialectics, which contribute to the study of the features of the practice of the member states of the European Union in the field of anti-corruption regulation. The methodological significance of the dialectical method in the study of the practice of the European Union member states in the field of anti-corruption regulation lies in the fact that it serves as a means of searching for new results, a method of transition from the already known to the unknown and new. This means that research not only transforms previously created theoretical knowledge about the practice of European Union member states in the field of anti-corruption regulation, but also forms their new modification by systematically adding new theoretical provisions.

One of the methodological techniques used in the research process was an integrated approach, which significantly overcame the shortcomings of analytical jurisprudence, since it made it possible to organically combine legal instruments and basic legal ideas, the principles of European Union law. For a comprehensive study of the problem, the regulatory framework consisted of the primary and secondary legislation of the European Union, as well as the national legislation of individual European Union member states. In turn, the sources of the study were fundamental monographs, scientific articles by domestic and foreign authors on the fight against corruption in the European Union. 


\section{RESULTS}

One of the effective tools to counter and prevent corruption is to ensure uniform high standards of anti-corruption legislation. However, it was not until the 1990s that anticorruption issues first emerged as a problem that could no longer be addressed only at the national level by EU Member States, but had to be dealt with at the supranational level. In particular, in 1997, the EU Commission planned to develop a far-reaching anti-corruption policy at the EU level. Later in 1997, the EU Commission published its first Communication on EU Anti-Corruption Policy, the EU's first policy document focusing exclusively on corruption ${ }^{27}$ (European Commission, 1997). In that Communication, the EU Commission also gave its first definition of corruption as any abuse of power or misconduct in the decision-making process caused by some illegal incentive or benefit'.

It should be noted that today the EU anti-corruption acquis consists of numerous legal and political acts, which are quite extensive. Moreover, there is an anti-corruption system in the European Union, which is mandatory for EU Member States and to which candidate countries must comply. The European Union has the right to act in the field of anti-corruption policy within the limits established by the Treaty on the Functioning of the European Union. In particular, the EU must ensure a high level of security, including by preventing and combating crime. Thus, in Article 83 of the Treaty on the Functioning of the European Union, ${ }^{28}$ corruption, together with terrorism, trafficking in human beings and sexual exploitation of women and children, illicit drug trafficking, illicit arms trafficking, money laundering, counterfeiting, computer crime, and organized crime refers to the area of particularly serious crime of cross-border content.

It can therefore be said that the European Parliament and the Council can establish minimum rules for the definition of criminal offences and sanctions in the field of corruption, using the directives adopted in accordance with the normal legislative procedure. Accordingly, the following anti-corruption legislation is currently in force within the European Union: the 1997 Convention on the fight against corruption involving officials of the European Communities or officials of Member States of the European Union, Framework Decision to Criminalize Corruption in the Private Sector $\mathrm{EU}$ of $2003,{ }^{29}$ and the 2017 Directive on the protection of the Union's financial interests.

In addition, it should also be noted that European legislation in other areas, such as the fight against money laundering and public procurement, also includes important anti-corruption provisions. The 1997 Convention on the fight against corruption involving officials of the European Communities or officials of Member States of the European Union $^{30}$ aims to ensure that each EU country takes the necessary measures

27 European Commission 'Communication on a Comprehensive European Union Policy against Corruption' (1997) <https:// eur-lex.europa.eu/LexUriServ/LexUriServ.do?uri=COM:1997:0192:FIN:EN:PDF> (21 May 1997)

28 Verkhovna Rada of Ukraine 'Consolidated Versions of the Treaty on European Union and the Treaty on the Functioning of the European Union' (1957) <https://zakon.rada.gov.ua/laws/show/994_b06\#Text> (25 March 1957)

29 European Parliament 'Communication from the Commission to the Council, the European Parliament and the European Economic and Social Committee on a Comprehensive European Union Policy against Corruption' (2003) < https://eur-lex. europa.eu/LexUriServ/LexUriServ.do?uri=COM:2003:0317:FIN:EN:PDF> (28 May 2003).

30 Council of the European Union-General Secretariat 'Convention Drawn up on the Basis of Article K.3 of the Treaty on European Union on the Fight against Corruption Involving Officials of the European Communities or Officials of Member States of the European Union' (1997) <https://eur-lex.europa.eu/legalcontent/EN/TXT/?uri=celex\%3A419 97A0625\%2801\%29>(25 June 1997). 
to criminalize corruption involving civil servants. In addition, it is designed to fight corruption with the participation of European or national officials of EU countries and strengthen judicial cooperation between the EU countries in this area. The Convention has a criminal law character and establishes obligations for the participating states aimed at criminalizing actions that constitute passive and active corruption of officials of the European Community and the Member States of the European Union. Under Article 2 of the Convention, States parties are obliged to take the necessary measures to prosecute and convict officials.

However, the Convention applies only to officials working in the public authorities of the Member States of the European Union or the European Community and does not cover acts of corruption committed in the private sector. It has a narrower scope than the Council of Europe Convention on the Criminal Liability for Corruption, which applies to acts of corruption in both the public and private sectors. Under Article 37 of the Convention, its jurisdiction covers offences committed in the territory of a State party by one of its nationals, as well as in relation to a national official or an official of the European Community, who is its national. The Convention also incorporates traditional international anti-corruption treaties on the obligations of States parties to cooperate in extradition and to provide each other with legal assistance in existing criminal investigations and judicial proceedings.

The EU Directive 2017/1371 replaced the Convention on the Protection of the European Communities' Financial Interests and its protocols by 6 July 2019. ${ }^{31}$ The Directive gives a new impetus to the fight against fraud affecting the financial interests of the European Union, requiring Member States to criminalize a number of behaviors that may affect such interests, namely fraud, money laundering, corruption, and embezzlement. These types of offences have already been included in the above-mentioned EU documents on corruption, with the exception of misappropriation, which was ignored by all anti-corruption documents, so the reference to this behavior in the Directive is a positive aspect as it is directly related to public funds management. In addition, the new Directive is very relevant as it proposes an updated definition of fraud, provides for the harmonization of penalties, and establishes a new aggravating circumstance when the offence is committed within a criminal organization. Also, the provisions on sanctions for entities not covered by the Second Protocol and the provisions on two important measures in the fight against corruption and other economic crimes, the freezing and forfeiture of the instruments, and proceeds of the above-mentioned activities, are criminal offences in the Directive.

In addition, Eurojust and Europol are the EU institutions that facilitate the cooperation of national investigators, courts, and prosecutors in the fight against corruption. Moreover, the European Anti-Fraud Office has also contributed to the fight against cross-border crime and crimes against the EU's financial interests. It is also envisaged that the European Public Prosecutor's Office will continue to operate in the field of anti-corruption. Thus, Eurojust can act when two or more Member States of the European Union have suffered from the crime of corruption. However, Eurojust itself

31 European Parliament 'Directive (EU) 2017/1371 of the European Parliament and of the Council of 5 July 2017 on the Fight against Fraud to the Union's Financial Interests by Means of Criminal Law' (2017) <https://eur-lex.europa.eu/legalcontent/EN/TXT/?uri=CELEX\%3A32017L1371> (5 July 2017). 
is not empowered to investigate and prosecute crimes. It works to coordinate investigations and prosecutions between EU Member States in cross-border crime cases. It may also facilitate investigations and prosecutions between the requesting EU Member State and a third country where there is a cooperation agreement or when there is a special need. ${ }^{32}$

Europol, through its Economic and Financial Crime Center, continues to support investigations into the elimination of criminal networks that launder their criminal profits through sports corruption or increase their illegal assets by manipulating sporting events around the world. The European Anti-Fraud Office, established in 1999 , is the central body aimed at detection and combating corruption that harms the EU's financial interests. Nowadays it operates on the basis of Regulation 883/2013. ${ }^{33}$ In particular, the European Anti-Fraud Office protects the EU's financial interests by investigating fraud, corruption and any other illegal activity. The European AntiFraud Office identifies and investigates serious issues related to the professional duties of members and staff of EU institutions and bodies, which can lead to disciplinary or criminal proceedings.

The European Anti-Fraud Office is able to conduct two types of investigations: internal and external. Internal investigations are conducted within EU institutions, bodies, offices, and agencies. External investigations involve the intervention of the European Anti-Fraud Office in the Member States in accordance with EU law. However, it should be noted that the European Anti-Fraud Office conducts administrative investigations. It has no judicial power to oblige national law enforcement agencies to act on its further recommendations. In addition to the important role of Eurojust and Europol in the fight against corruption, from the end of 2020 the European Public Prosecutor's Office, which is an independent and decentralized Public Prosecutor's Office of the European Union, will also work in this area. It will investigate, prosecute and prosecute crimes of fraud and corruption against the EU budget. The uniqueness of this prosecutor's office is the power to prosecute at the European Union level for fraudulent actions aimed at the EU budget, including corruption. ${ }^{34}$

Anti-corruption work also continues within a network such as the European contact-point network against corruption (Official Journal of the European Union, 2008). In particular, the functions of the Network include (i) providing a forum for the exchange of information on effective measures and experience in preventing and combating corruption in the European Union and (ii) promoting the establishment and

32 European Parliament 'Regulation (EU) 2018/1727 of the European Parliament and of the Council of 14 November 2018 on the European Union Agency for Criminal Justice Cooperation (Eurojust), and Replacing and Repealing Council Decision 2002/187/JHA' (2018) <https://eur-lex.europa.eu/legal-content/en/TXT/?uri=CELEX\%3A32018R1727> (21 November 2018).

33 European Parliament 'Regulation (European Union, Euratom) No 883/2013 of the European Parliament and of the Council of 11 September 2013 Concerning Investigations Conducted by the European Anti-Fraud Office (OLAF) and Repealing Regulation (EC) No 1073/1999 of the European Parliament and of the Council and Council Regulation (Euratom) No 1074/1999' (2013) <https://eur-lex.europa.eu/legal-content/EN/TXT/?uri=CELEX\%3A32013R0883> (18 September 2013).

34 The European Public Prosecutor's Office 'Publications Office of the European Union' (2017) <https://op.europa.eu/en/ publication-detail/-/publication/57867c4b-0690-11ea-8c1f-01aa75ed71al> (13 November 2019). 
active maintenance of contacts between its members. Members of the Network shall meet at least once a year to carry out their functions. ${ }^{35}$

In 2008, the EU acceded to the UN Convention against Corruption, which is the most comprehensive instrument in the global fight against corruption, having 186 signatories. It should be noted that among the most important provisions of this Convention, according to which member states provide for the introduction into national law of such areas of anti-corruption, are as follows: the establishment of a special body (bodies) aimed at preventing and combating corruption; active public participation in the field of prevention of corruption, creation of codes of conduct for employees; strengthening the independence of the judiciary; consolidation of criminal liability for corruption offenses and delineation of corruption crimes; and establishing the responsibility of legal entities. ${ }^{36}$ [In addition,] In July 2019, the EU joined GRECO, a group of anti-corruption states operating within the Council of Europe with observer status, which is the first step towards full membership in GRECO. The aim of GRECO is to improve the capacity of its members to fight corruption by monitoring their compliance with the Council of Europe's anti-corruption standards through a mutual evaluation process.

\section{DISCUSSION}

The nature, scope, and effectiveness of anti-corruption policies vary from Member State to Member State. Although the nature and extent of corruption varies from country to country, it affects all countries of the world, including the member States of the European Union. Member States of the European Union are to be commended for demonstrating effective and efficient ways of combating corruption by making the European Union a world leader in the fight against corruption. That is why the six member States of the European Union, namely Denmark, Finland, Sweden, the Netherlands, Germany, and Luxembourg, are among the top 10 countries with the lowest level of corruption.

According to the World Bank classification, ${ }^{37}$ there are two types of corruption: administrative corruption and state corruption. Administrative corruption is defined as bribery faced by ordinary citizens, for example, in contacts with officials, police, and the health service. State corruption occurs when the processes of lawmaking, public administration, or the judiciary are appropriated by individuals or groups who promote decisions that are good for them but bad for the majority of society. Administrative corruption is sometimes referred to as 'daily corruption' and state corruption as 'political corruption'.

For example, V Terpak in his research identifies two main models of anti-corruption activities, namely vertical and horizontal strategies. In particular, the vertical strategy for combating corruption is to achieve results quickly, the consequences of which are not the complete elimination of corruption, but the achievement of a certain level of corruption acceptable to the government and society. At the same time, the horizontal strategy is focused on gradual improvement, based on anti-corruption incentives, and

35 Official Journal of the European Union 'Council Decision 2008/852/JHA of 24 October 2008 on a Contact-Point Network against Corruption' (2008) <https://eur-lex.europa.eu/legal-content/EN/TXT/?uri=celex\%3A32008D0852>.

36 K Rostovska 'International Experience in the Formation and Implementation of Anti-corruption Policy in Other Countries' (2017) 4 Aktualni Problemy Pravoznavstva 119.

37 The World Bank 'Anticorruption in Transition' (2001) <http://documents1.worldbank.org/curated/ en/825161468029662026/pdf/multi-page.pdf> (September 2000). 
long-term anti-corruption activities. It is the horizontal model of combating corruption that is characteristic of the member states of the European Union (Sweden, Denmark, Finland, and the Netherlands).

In turn, T Khabarova, studying the anti-corruption policies of Finland, Denmark, and Sweden, notes that they have a certain feature that reduces corruption-that is, the openness of the authorities, moral and psychological rejection of corruption by citizens, increasing transparency, and promoting involvement of the population in the implementation of anti-corruption measures. In other words, a number of ethical (for employees) and moral (for the whole society) principles are applied, which do not allow citizens to commit acts of corruption. ${ }^{38}$ For example, in Danish culture, much attention is paid to openness of information and the informed public. Open and transparent governance is considered a prerequisite for preventing and disclosing corruption and governance shortcomings. In addition, the maximum penalty for active bribery in the public sector has increased from three to six years. For bribery in the private sector and bribery of arbitrators, the maximum penalty has been increased from one year and six months to four years. ${ }^{39}$ Access to information is regulated by law, and anyone can access the documents of any state administrative figure.

A well-functioning criminal justice system capable of handling corruption cases at a high level and with independent prosecutors exists, for example, in Finland. ${ }^{40}$ The principle of free access to state registers is enshrined in the Constitution, as well as in the Law on Openness of State Activity. In Sweden, low levels of corruption are linked to a long tradition of openness and transparency in Swedish society and its institutions, and a strong respect for the rule of law. In addition, the National Anti-Corruption Unit of the Prosecutor General's Office was established in 2003. The unit examines all suspected bribery, both transmission and receipt, as well as suspicions related to such crimes. $^{41}$

The Netherlands also has a low level of corruption. The National Penal Code prohibited bribery in the public or private sector and bribery of foreign Government officials. Extortion, abuse of functions, fraud, and money laundering are criminal offences. Dutch and foreign companies and their subsidiaries may be held liable for corruption offences committed by persons acting on their behalf. Individuals can be fined up to 78,000 euros and/or sentenced to up to six years in prison and a maximum penalty of 12 years for bribing judges. ${ }^{42}$

In Germany, according to the original German doctrine, an official is considered a servant, body, and representative of the state. ${ }^{43}$ [In addition,] The German Criminal Code $^{44}$ classifies three different forms of bribery and corruption: (i) bribery in

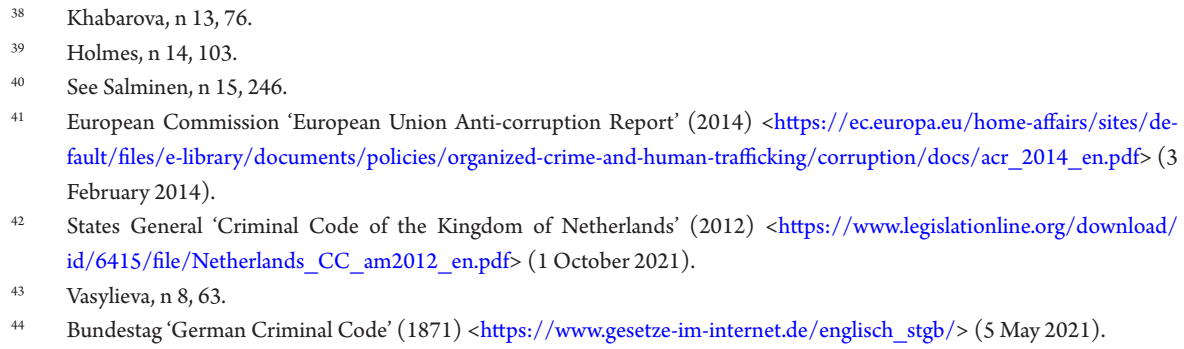


business relations and the health sector; (ii) bribery of civil servants; and (iii) election bribery. However, in all three areas mentioned above, it is important to prove that the parties have agreed to enter into an illegal agreement, even if the agreement was made informally. The Luxembourg Criminal Code provides for the same penalties for civil servants as for those who corrupt civil servants. In particular, it imposes penalties such as imprisonment from 5 to 10 years and/or a fine of 500187,500 euros. ${ }^{45}$ In addition, soft law instruments have been developed to prevent and combat corruption, establishing an ethical framework for judges and members of the government.

In recent years, Denmark has topped the annual ranking as one of the least corrupt countries. It is characterized by information transparency of state structures and freedom of access of the press to the documents on which these decisions are based. There is no specialized anti-corruption body, only key public and private anti-corruption initiatives related to the conduct of business controlled by NGOs. Anti-corruption activities in Denmark are aimed at preventive measures. In particular, the Danish international development agency Danida, which implements development programs and provides interest-free loans to finance projects, develops a policy of absolute intolerance of corruption within the company and in cooperation with external partners. All Danida contracts contain anti-corruption provisions that apply to all terms of the contract, i.e. companies must enter into a declaration prohibiting bribery as a manifestation of corruption. Violation of the relevant provision leads to termination of the contract and refusal of further partnership.

We will also focus our attention on anti-corruption activities in the policy area of individual EU member states. As an example, we have chosen two of the old members of the European Union-France and Finland-as being among the few European countries with minimal corruption, and a number of new members of the Union-Eastern and South-Eastern Europe. They are united by the process of implementation of European anti-corruption norms in national legal and institutional systems; they are members of pan-European cooperation in combating corruption. At the same time, they differ in their approaches to implementing mechanisms to combat political corruption in public administration, which depend on the severity of the problem, the political will of the government, the level of public support for anti-corruption reforms, and the culture, mentality, political tradition and history of these countries.

France's current legal anti-corruption mechanism aims to combat the official crimes of public officials who make political and administrative decisions, as well as to combat the illegal activities of political parties and their heads in public authorities that use illegal methods of financing and conducting election campaigns. At the same time, French law focuses mainly on administrative rather than punitive measures. [At the same time,] The main goal is to prevent 'illegal combination of personal financial interests and performance of official functions of a civil servant'.

45 Chamber of Deputies of Luxembourg 'Criminal Code of the Grand-Duchy of Luxembourg' (1879) <https://www. legislationline.org/documents/section/criminal-codes/country/16/Luxembourg/show> (1 November 2018). 
At the heart of the legal anti-corruption mechanism of modern France are the following instruments:

- Constitution. ${ }^{46}$ Under this, government officials are prohibited from combining their positions with parliamentary or senate mandates and with any other professional activity in the public or private sector. After resignation, ministers are not allowed to hold senior positions in public or private companies for six months;

- Resolutions of the Government of the country of 11 March 1988 on the publication of acts of political parties and data on the costs of election campaigns, on the mandatory declaration of income of ministers and parliamentarians; ${ }^{47}$

- The Law on the Financing of Political Parties (1990), which introduced restrictions on the provision of funds, including for election campaigns, to political parties from individuals or enterprises; ${ }^{48}$

- Law 'On Prevention of Corruption and Transparency of Procedures in Public and Private Organizations. ${ }^{49}$ The law provided for a number of measures, including the establishment of the Central Anti-Corruption Service, the introduction of stricter and more transparent rules for financing political parties and election campaigns, the conclusion of government contracts to increase transparency in this area and strengthen control over local government.

At the institutional level, the fight against political corruption in public authorities is headed by: the Commission on Financial Publicity of Political Life, which monitors the property status of parliamentarians; National Commission on Campaign Accounts and Financing of Political Parties (endowed with control functions); law enforcement agencies such as the Anti-Money Laundering Organization TRASFIN, the Ministry of Justice, the Anti-Corruption Division established in 2004 as part of the Judicial Police's Office for Combating Economic and Financial Crimes, and the Central AntiCorruption Service, which cooperates with the above law enforcement agencies.

These anti-corruption mechanisms, of course, contributed to a certain 'moralization' of public administration. Although the issue of political corruption in public administration remains relevant to this day. An important factor contributing to the success of these measures at the national level is also France's active participation in the EU's anti-corruption activities.

46 National Assembly 'Constitution of France' (1958) <https://www.legifrance.gouv.fr/loda/id/JORFT EXT000000571356/2019-07-01/> (1 July 2019).

47 National Assembly 'Resolutions of the Government of the Country on the Publication of Acts of Political Parties and Data on the Costs of Election Campaigns, on the Mandatory Declaration of Income of Ministers and Parliamentarians' (1988) <https://www.legifrance.gouv.fr/loda/id/JORFTEXT000000321646/> (11 March 1988).

48 National Assembly 'The Law on the Financing of Political Parties which Introduced Restrictions on the Provision of Funds, Including for Election Campaigns, to Political Parties from Individuals or Enterprises' (1990) <https://dialnet.unirioja.es/ descarga/articulo/5801819.pdf> (January-December 2016).

49 National Assembly 'On Prevention of Corruption and Transparency of Procedures in Public and Private Organizations' (1993) <https://www.legifrance.gouv.fr/loda/id/JORFTEXT000000711604/> (29 January 1993). 
France has ratified all known anti-corruption conventions of the European Union, and its law enforcement agencies are actively cooperating with Europol, Eurojust, etc. The objective factors inherent in globalization processes also contribute to overcoming political corruption in the public sector. In particular, such factors as: increasing the role of network management compared to the hierarchical 'vertical of power', reducing the presence of the state in the real economy, deregulation of services, and so on. As a result, the symbiosis of politicians, businessmen and bureaucrats typical of France throughout its long history is gradually giving way to each of the three elites focusing on their direct purpose, which affects their system of formation, restructuring and, consequently, the nature of relations.

The experience of Finland is a rather illustrative example of the balanced implementation of European Community law into national legislation and the application of precautionary tools to combat political corruption in the system of public administration. For many years in a row, Transparency International has identified this country as one of the least corrupt countries among 133 countries. It ranks fourth in the ranking. As a member of the European Union, Finland is a party to all major EU anti-corruption regulations.

The main principle of implementation of European laws in the national legal system is an organic combination of the national legislation of this country with the European one with the minimum possible changes of the first. Thus, in Finland there is no special strategy for combating political corruption in public authorities. There are also no special anti-corruption laws. Instead, the country has precautionary anti-corruption rules in a number of legal acts on the civil service and the financing of political parties.

Thus, the Constitution of Finland ${ }^{50}$ provides guarantees against the abuse of state power. In particular, it regulates decisions on the appointment of high-ranking government officials. It is accepted on a competitive basis and takes into account special requirements for ethics and morals. In turn, the Law 'On Civil Servants' of $1994^{51}$ provides for the submission by public servants of a declaration of participation in commercial activities, personal loans, property, additional work. The Law 'On Security Verification' ${ }^{52}$ defines the conditions for verification of the data of persons who apply for a certain position.

[In addition,] The Constitution, as well as the 1999 Law on Openness of the Government, ${ }^{53}$ guarantees the openness of official state documents. According to the law, all documents of state and municipal structures are considered public, unless a special decision has been made on them. If only part of the document is designated as secret, then other points of the document remain in the public domain. The law also sets out the conditions for exercising the right of access to official documents. Citizens have the right to request access to documents orally, by telephone, in writing, by e-mail, or at a reception. 
Despite the absence of special anti-corruption bodies and laws, and a number of rather nontransparent rules in legislation that provoke the risk of political corruption in the civil service, the general principles of openness, transparency, and transparency of public administration are considered central to public services in Finland. It should be acknowledged that the least affected by political corruption in the EU is not entirely due to the influence of European community norms, but the transparency of national government, a significant level of political culture of officials, significant public activity (its role is played by the media in Finland), and high public confidence in the authorities. $^{54}$

In Central and Eastern Europe, much attention is paid to the adoption of detailed anti-corruption laws aimed at criminalizing the full range of bribery; most countries have also implemented anti-corruption programs at the national level. The response to the fight against corruption in many EU countries has been an increase in the number of anti-corruption by-laws. Fighting corruption as one of the top priorities of the Czech government is based on the government's anti-corruption strategy throughout. The strategy is divided into two parts, namely analytical and strategic.

The analytical part consists of three sections: perception of corruption, qualitative analysis of economic aspects of corruption, detection, and investigation of corruption. The strategic section contains the main strategic directions. These include professionalization of public administration; management of state property; strengthening of anticorruption tools in the private sector; strengthening of the political system and increasing transparency of political parties; detection, investigation, and prosecution of corruption offences; strengthening of the anti-corruption climate in Czech society; monitoring of corruption, and coordination of anti-corruption policy; strengthening resources for the implementation of anti-corruption policy; increasing transparency in the public sector.

According to international experience, the fight against corruption succeeds only if it is comprehensive, when it covers as many areas of the state as possible, is ongoing and is the focus of both government and the public. Such activities in most European countries, including Slovakia, are carried out systematically and are based on the basic principles of the rule of law, legality, system, practical orientation, and radical measures of interaction of government agencies with institutions of society and the population and more. The peculiarity of anti-corruption policy in the Slovak Republic is that the Central Anti-Corruption Coordination Office and the Anti-Corruption Committee were abolished and the Anti-Corruption Department of the Secretariat of the Slovak Government was established to coordinate anti-corruption ministries and agencies. The Anti-Corruption Office of the Presidium of the Police Corps of the Ministry of the Interior of Slovakia and the Slovak Information Service are directly involved in the implementation of measures within the framework of the National Anti-Corruption Program. In addition, the main anti-corruption powers have been transferred from the Ministry of Finance to the Ministry of Justice of Slovakia. The Ministry of the Interior of the Slovak Republic has an Anti-Corruption Committee, which is responsible for taking preventive measures and investigating corruption among employees of the Ministry and police structures of the country.

54 AL Tinkov 'Features of Combating Political Corruption in EU Countries' (2014) 1 National Academy of Public Administration under the President of Ukraine $8<$ http://academy.gov.ua/ej/ej14/txts/Tinkov.pdf>. 
Romania is characterized by the most aggressive anti-corruption policy in the European Union. In 2002, the Romanian National Anti-Corruption Directorate was established, modeled on Italy, to detect and investigate corruption offenses. Attempts to avoid liability of individuals necessitated the provision of the Romanian Code of Criminal Procedure (Parliament of Romania, 1991) to provide mutual information to law enforcement agencies about the crossing of the border by suspects. Within the framework of international cooperation, there are joint investigation teams, which makes it possible to effectively identify persons who are internationally wanted. It is difficult to obtain information from providers, as well as to obtain permission to search politicians when these individuals are only involved in corrupt transactions. Romania's membership in the European Union makes it possible to cooperate quickly, in particular to verify the legality of funds found during customs control at the airport within eight hours, regardless of the place of detention..$^{55}$

\section{CONCLUSION}

The processes of globalization taking place in the modern world are becoming the basis not only for the development of international socio-economic relations, cultural integration, and legislative unification, but also contribute to such negative phenomena as transnational crime, including transnational corruption. Corruption is a global problem in many modern countries. It creates an obstacle to normal, progressive economic and social development. For decades, the world community has stressed the need to address this issue. The result of this international policy was the adoption of a set of international legal instruments prepared and adopted in the European Union. It is difficult to overestimate the importance of international experience in preventing corruption crime.

Studying the content of the legal sphere of prevention and counteraction to corruption, which determines the elements of anti-corruption activities, it is necessary to point to the norms of international law, which form the external relevant criteria for the development of prevention and counteraction to corruption. In particular, the principles of international law are characterized as imperative, fundamental, universal rules of international law that ensure the main interests of mankind. The principles of preventing and combating corruption are the basis of the anti-corruption strategy, so the analysis of international best practices in the fight against corruption allows us to identify the most effective international principles for combating corruption.

Analysis of international best practices in the fight against corruption shows the effectiveness of such international anti-corruption principles as proper management of state affairs and state property, law and order, integrity, honesty, transparency, and accountability, limiting immunity from prosecution for corruption, guaranteeing national and international recognition of (criminal) corruption, prevention of corruption, autonomy, independence, and freedom of persons responsible for bringing others to justice for acts of corruption. A notable foreign approach to the list of acts that qualify as corruption crimes.

ss T Humeniuk 'Responsibility of Civil Servants for Corruption' (2020) 5 Legal Bulletin 129. <http://yuv.onua.edu.ua/index. php/yuv/article/view/2011/2136>. 
Thus, we can talk about the existence of a competitive and alternative international system of anti-corruption mechanisms, which allows interested countries or organizations to implement separate, though internationally developed, anti-corruption mechanisms. Thought-out correlation and harmonization of international and domestic principles of preventing and combating corruption is the key to effective fight against corruption and gives hope for the possibility of long-term minimization of such illegal acts. 